\title{
Project for the Notification and Follow-up of COVID-19 at Hospital CUF Sintra
}

\section{Projeto de Notificação e Seguimento da COVID-19 no Hospital CUF Sintra}

Patrícia Mora¹, Matilde Lagoa², Carolina Baltazar², Diogo Carvalho², Gonçalo da Câmara², Filipe Modesto², Catarina Pohle², Sandra Fernandes², Patrícia Salvador², Inês de Sousa², André Guerreiro², Francisco Faustino², Sofia Ramalho

\begin{abstract}
First discovered in the Chinese province of Wuhan, in early December 2019, the infection by the new coronavirus led to a pandemic prompting the declaration of an International Public Health Emergency by the World Health Organization on the $30^{\text {th }}$ of January 2020. In Portugal, the first cases date from the $3^{\text {rd }}$ of March 2020 with more than 24600 positive cases of the 247000 suspected cases within only two months. Given the seriousness of the situation, a National State of Emergency was declared on the $18^{\text {th }}$ of March and extended on April $2^{\text {nd }}$ and $17^{\text {th }} 2020$.

Consequently, and according to the official statement issued by NOVA Medical School in accordance with the previous statement from the NOVA University of Lisbon and the Council of Portuguese Medical Schools regarding the containment measures to be implemented, all clinical practise activities were suspended. In light of this reality, the senior year finalists revealed motivation in playing an active role during the outbreak, showing availability to collaborate with the local authorities and health professionals. A partnership was hence established with the José de Mello Saúde/CUF Health Unit, that supported this initiative by integrating students at the CUF Sintra Hospital (one of its COVID-free units) in administrative tasks under guidance and tutoring of Patrícia Mora, MD.

The project started on the 31 $1^{\text {st }}$ of March 2020, with the students collaborating in case notifications on the platform of the National Epidemiological Surveillance System, an instrument that has been essential in collecting representative data for the elaboration of national response strategies, and later updating the internal database. This project contributed to significantly reduce the administrative burden of health professionals with appreciable gains in the availability of doctors and nurses for the assistance and provision of differentiated care and follow-up of clients with or without infection with the new coronavirus
\end{abstract}

KEYWORDS: COVID-19; Disease Notification; Pandemics 


\section{RESUMO}

Com início em dezembro de 2019, na província chinesa de Wuhan, a infeção pelo novo coronavírus originou uma pandemia que levou à declaração de uma Emergência de Saúde Pública Internacional pela Organização Mundial da Saúde a 30 de janeiro de 2020. Em Portugal, os primeiros casos datam a 3 de março de 2020 e ao fim de dois meses, contavam-se mais de 24600 casos positivos dos cerca de 247000 casos suspeitos. Face à gravidade da situação, foi declarado o Estado de Emergência Nacional a 18 de março, prorrogado a 2 e 17 de abril de 2020.

Consequentemente, e de acordo com o comunicado oficial da NOVA Medical School em conformidade com o parecer da Universidade NOVA de Lisboa e Conselho de Escolas Médicas Portuguesas, todas as atividades letivas presenciais foram suspensas. Sensibilizados para o problema, os finalistas do curso de Mestrado Integrado em Medicina prontificaram-se a ajudar no combate à pandemia. Estabeleceu-se assim uma parceria com a Unidade de Saúde José de Mello Saúde/CUF, que se disponibilizou para apoiar esta iniciativa integrando os alunos no Hospital CUF Sintra, um dos seus espaços COVID-free, em tarefas de índole burocrática sob orientação e tutoria da Dra. Patrícia Mora.

O projeto iniciou-se a 31 de março de 2020, ficando os alunos responsáveis por colaborar na realização de notificações na plataforma do Sistema Nacional de Vigilância Epidemiológica, uma ferramenta que tem sido fundamental na recolha de dados representativos para elaboração de estratégias nacionais de resposta, e posterior atualização da base de dados interna. Este projeto permitiu diminuir significativamente a carga burocrática dos profissionais de saúde com ganhos valorizáveis na disponibilidade destes para o atendimento e prestação de cuidados diferenciados e seguimento dos clientes com ou sem a infeção pelo novo coronavírus.

PALAVRAS-CHAVE: COVID-19; Notificação de Doenças; Pandemia

\section{INTRODUCTION \\ EPIDEMIOLOGICAL CONTEXT}

The coronavirus disease (COVID-19) is an infection caused by the coronavirus of severe acute respiratory syndrome 2 (SARS-CoV-2), first isolated in January 2020. ${ }^{1}$ The first reported cases, in December 2019, were described in a group of individuals diagnosed with pneumonia of viral etiology and reported a relation to a shellfish marked in Huahan in the Chinese province of Wuhan. ${ }^{2}$ From there, the disease spread globally and was hence declared a Public Health Emergency by the World Health Organization on the $30^{\text {th }}$ of January 2020. ${ }^{3}$

In Portugal, the first cases of COVID-19 were identified on the $3^{\text {rd }}$ of March 2020. ${ }^{4}$ Within 2 months, from around 247000 suspected cases, more than 24600 cases were positive, from which 14638 were women (59\%) and 10054 were men (41\%), with a death toll of 989 until the $30^{\text {th }}$ of April. The clinical presentation of confirmed cases was cough (50\%), fever (36\%), myalgia (25\%), headache (23\%), fatigue (19\%) and breathing difficulty $(15 \%) .5$

The State of National Emergency was officially declared in Portugal on the $18^{\text {th }}$ of March 2020 and renewed on the $2^{\text {nd }}$ and $17^{\text {th }}$ of April 2020. It issued a generalized obligation to stay indoors, restricting circulation. ${ }^{6} \mathrm{Ad}-$ ditionally, the General Directorate for Health promoted specific recommendations including hand hygiene, respiratory etiquette and social distancing to be adopted by the general population for infection prevention particularly important during the mitigation phase.

\section{NATIONAL SYSTEM FOR EPIDEMIOLOGIC SURVEILLANCE}

The National System for Epidemiologic Surveillance (SINAVE), implemented in 2009 and managed by the General Directorate for Health is a surveillance system in public health used to notify communicable diseases by various institutions from the public, private and social sectors. This platform allows for the identification of high-risk situations as well as collection and processing of data on communicable diseases and other situations representing a risk for public health, integrating clinical information and laboratory results.?

Given the present action against the pandemic caused by the COVID-19, the SINAVE has been shown to have a crucial role given the unprecedented high influx of data in such a short interval of time. On this platform, by answering to a questionnaire, doctors are able to notify suspected cases of the disease adding important information concerning concomitant symptoms, severity of presentation, client comorbidities, professional occupation, recent travelling and potential contacts with those diagnosed with COVID-19, allowing to trace the line of transmission. This allows real time acknowledging of the 
evolution of the number of cases, enabling health authorities to reach data-based decisions regarding the type of preventive and control measures to be implemented, in order to limit the spread of the disease and additional cases. ${ }^{7}$

\section{CONTRIBUTION FROM NOVA MEDICAL SCHOOL STUDENTS}

Given the COVID-19 pandemic and, according to the official statement issued by NOVA Medical School in accordance with the previous statement from the NOVA University of Lisbon and the Council of Portuguese Medical Schools regarding the containment measures to be implemented, all curricular activities were suspended. In light of this reality, the students, namely some seniors from the last year of the course were motivated to play an active role during the evolution of the outbreak, showing availability to collaborate, to the extent of their abilities, with the local authorities and health professionals.

Thus, the competent bodies of the faculty, working in parallel with the Students' Association, created a program for accessibility of students to Health Units willing to receive them on a voluntary basis, in order to collaborate with their professionals' teams.

The José de Mello Saúde/CUF Health Unit acted on valuing this desire for collaboration and offered to support this initiative with the integration of students in one of its COVID-free spaces (closed to the public access during the month of April), namely the CUF Sintra Hospital. In this context, the needs to be met and the tasks that would be performed were investigated as well as issues related to exposure and safety. It was concluded that the greatest contribution would be on assisting in case notification. On March 31'st 2020, once security conditions for students' involvement were warranted, the project was launched, with a working schedule between 8:00am and 6:00pm, at CUF Sintra Hospital, under guidance of Patrícia Mora, MD, coordinator of General Practice and Family Medicine at the Hospital. The team comprised 19 volunteer students, 13 doctors and 6 nurses.

Since it is an infectious disease of compulsory notification, for each suspect case the doctor is required to fill in the appropriate data on the SINAVE platform. In strict cooperation of the medical team, and after becoming familiarized with the SINAVE platform, the students assisted on the notification of the cases, assuring the confidentiality of the data. The testing for COVID-19 was carried out at CUF Infante Santo Hospital, while verification and notification of the result was done by the formed team at CUF Sintra Hospital. The monitoring of negative cases was carried out by the nursing team and that of the inconclusive and positive cases was assigned to doctors at CUF Sintra Hospital.

\section{OBJECTIVES}

The students from the final year of medical school took on certain bureaucratic tasks and helped in improving the communication with regulatory health entities. The main objective of this article is to describe the advantage of these students in assisting qualified medical work, due to their proximity to the conclusion of their medical education with inherent knowledge acquired at this phase and also because of their desire to start their professional career.

This article has specific objectives such as to i) describe the communication of results following the completion of the COVID-19 test performed at CUF Infante Santo Hospital; ii) describe the contact and follow-up procedure of the clients after getting tested for COVID-19 at CUF Infante Santo Hospital and iii) monitor the total number of clients tested at CUF Infante Santo Hospital. Finally, it is intended to evaluate the effectiveness and efficiency of the project to study its contribution, name the hardships, mostly related to the technicalities in filling the notification, and improve the response to an eventual new outbreak of the pandemic.

\section{METHODOLOGY}

The competent services of the NOVA Medical School and the Students' Association allowed the integration of twelve students in this health unit, which received students as volunteers. The recruitment was carried out by the Students' Association, which initially surveyed the availability of students, and received a total of 140 replies.

The project started on the $31^{\text {st }}$ of March 2020 with twelve volunteers in the first week, divided into shifts of 1 to 3 participants. Due to the increasing number of clients coming to the hospital and consequent increase of COVID-19 testing, the number of volunteers proved to be insufficient, leading to the integration of 7 new volunteers to the team of 12 , in the second week. In the first two weeks of the project, there was an increase in the demand of students per shift (2 to 3 ) to meet the increasing requirements associated with the rise in the number of cases. But as the progression of COVID-19 slowed, the number of volunteers per shift was reduced to 1 to 2 .

The volunteers were distributed according to a monthly schedule and to their availability into two daily sche- 
dules: 8:00 am to 1:00 pm and 1:00 pm to 6:00 pm. In the first week, the students organized themselves in groups of three, to whom initial training was provided by Patrícia Mora, MD. This training aimed to provide information on how to access clinical files and how to fill out notifications on the SINAVE platform, following the provided guidelines for COVID-19. The students were aided on the notification process under the strict guidance of the assistant doctor.

In the process three platforms were used: an internal database (HCIS_Comunicações and Follow-up_COVID19), the Glintt software and the SINAVE platform. In the beginning, the internal identification number of each client was searched in the database (HCIS_Comunicações and Follow-up_COVID19) and then the clinical file was accessed in the Glintt software. After logging into the SINAVE platform, personal data was filled in and the disease to be notified was chosen, in this case, "Coronavirus Infection". With the data previously collected from the Glintt software the notification was completed, including biochemical analysis. Finally, the internal database was updated with the corresponding notification number, assigned by the SINAVE platform.

The rest of the team was responsible for communicating the result of the COVID-19 test to the clients. Positive and inconclusive cases were followed-up daily by the medical team until they were asymptomatic, but never less than fourteen days for positive cases. The communication of the client's negative result was attributed to the nursing team that collaborated with the project. In both cases, additional information was provided, including measures to reinforce the social distance, handwashing, and respiratory etiquette, as well as disease red flags.

\section{RESULTS}

Regarding the results obtained, from the $31^{\text {st }}$ of March to the $30^{\text {th }}$ of April 2020, it was estimated the need for 930 hours of students' volunteer time of which only 540 hours were allocated according to students' daily availability. From the total of this time, 426 effective work hours were spent on the notification process.

From the $13^{\text {th }}$ to the $30^{\text {th }}$ of March CUF health professionals reported a total number of 477 cases, of which 61 had a positive result for the new coronavirus, representing $12.8 \%$ of the total cases reported. From the $31^{\text {st }}$ of March to $30^{\text {th }}$ of April a total number of 978 cases were reported by volunteers, of which 82 had a positive result for the new coronavirus infection. This represented $8.4 \%$ of the total cases reported. All together 1455 cases were notified, of which 143 had a positive result for the new coronavirus, representing $9.8 \%$ of the total cases reported (Fig. 1). The volunteer students helped

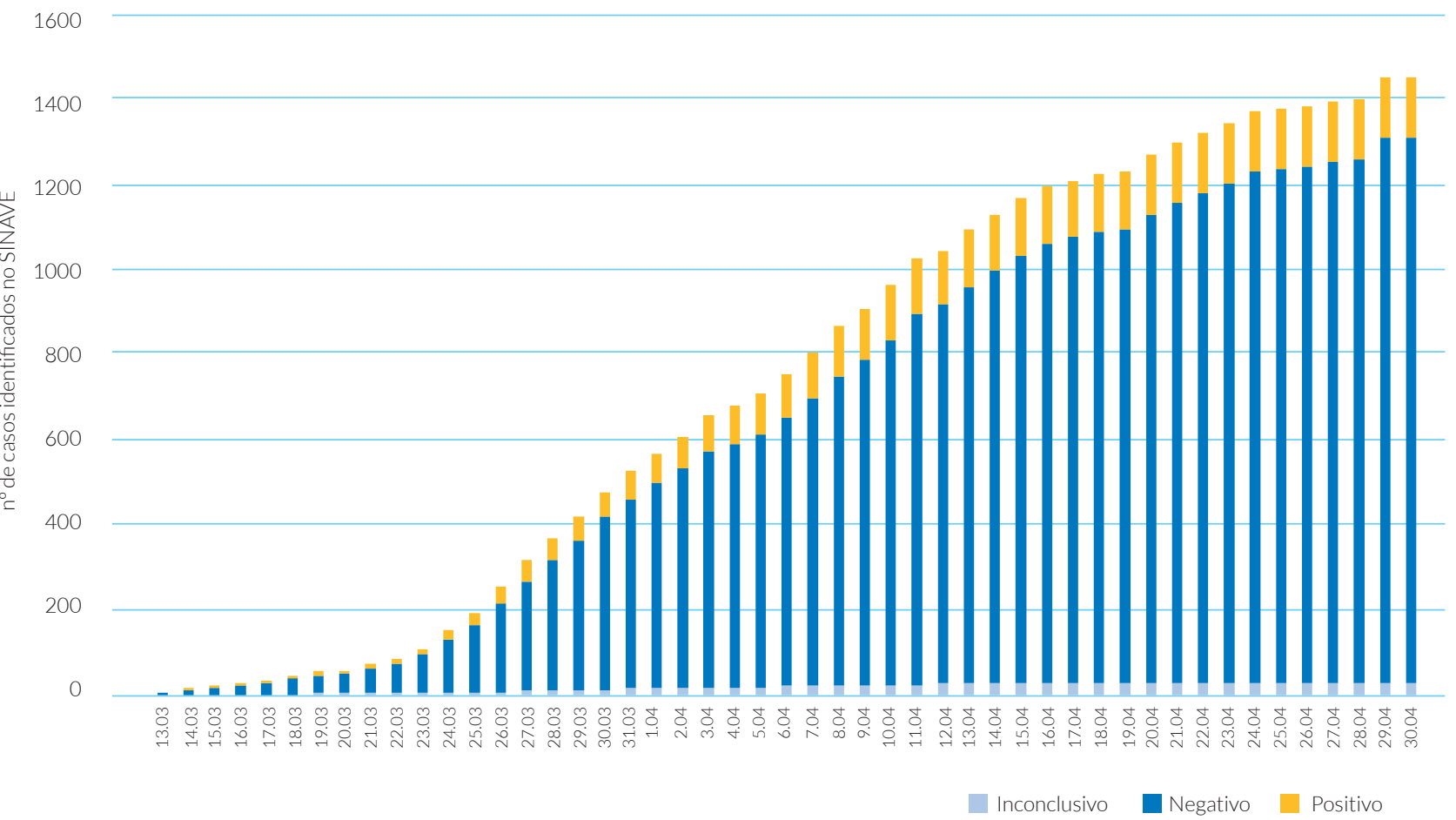

FIGURE 1. Number of inconclusive, negative and positive cases notified on the SINAVE notification platform from $13^{\text {th }}$ of March to $30^{\text {th }}$ of April 2020. 


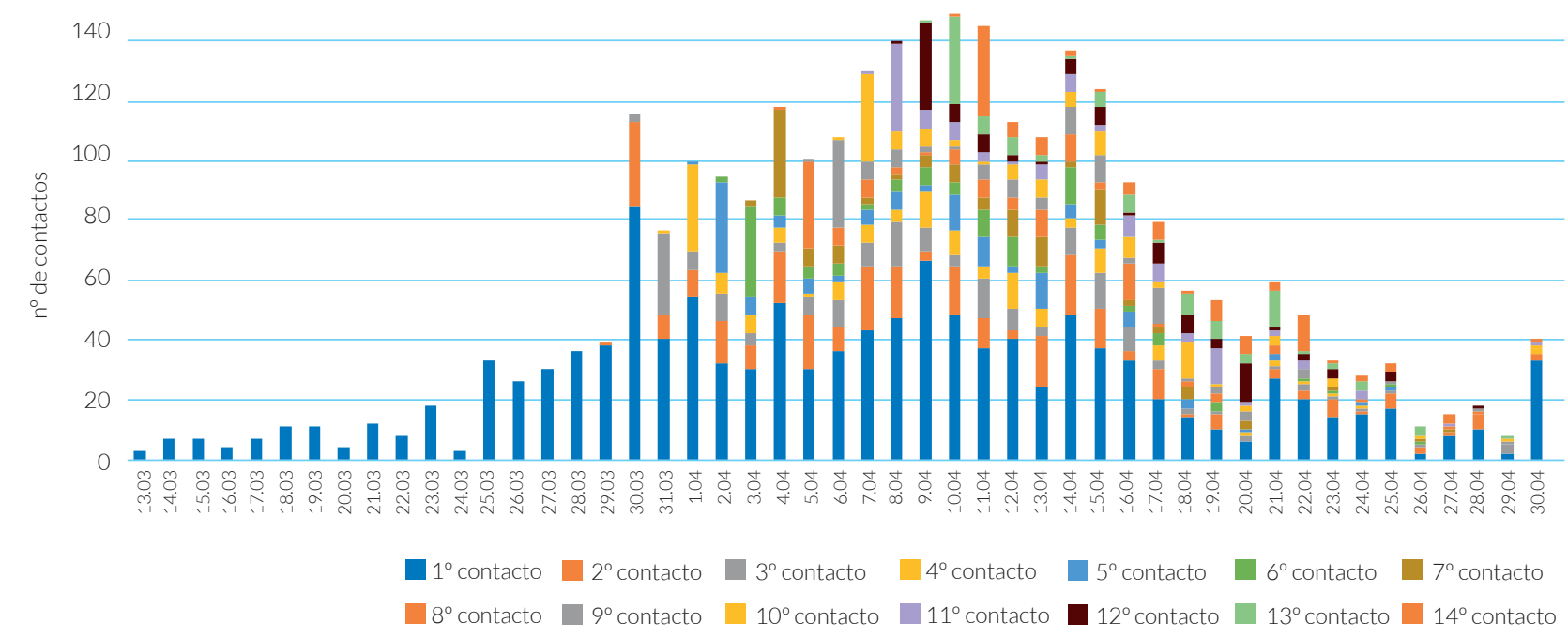

FIGURE 2. Number of telephone contacts carried out by the medical and nursing team to clients tested for the COVID-19 from the $13^{\text {th }}$ of March to the $30^{\text {th }}$ of April 2020.

to notify an estimate of $2 \%$ of the total positive cases in the area of great Lisbon.

The mean number of case reports done by each volunteer in their respective work shift was of 9 cases representing a mean notification time of 41 minutes. This was spent in multiple steps including verifying laboratory results, reading information regarding the clinical presentation profile, filling in the data on the SINAVE platform and updating the CUF Sintra database concerning the project. The mean time taken, exclusively on the SINAVE platform, per notification, was of approximately 1 minute and 30 seconds.

The volunteers' engagement allowed to significantly decrease the paperwork burden of CUF Sintra healthcare professionals. This contributed to unlocking hours that could now be spent on the follow-up and contact of positive and negative clients. Prior to the volunteers' contribution, medical staff completed a total number of 374 phone calls but could only assure that $81 \%$ of newly diagnosed clients had a first call within the first 24 hours. With the volunteers' contribution the number of phone calls increased significantly by $50 \%$, and it was possible to contact all tested clients in 24 hours. Since March 13th, 2850 phone calls were conducted, with respective distribution presented in Fig. 2.

\section{DISCUSSION}

The results clearly demonstrate that the participation of medical students in the context of a pandemic resulted in an increase in the efficacy and volume of work produ- ced, as seen by the total amount of notifications introduced in the SINAVE platform and by the amount of phone calls conducted.

We present here a significant time discrepancy between the average time spent on each notification, of 41 minutes, and the average time spent introducing the relevant clinical information in the SINAVE platform, of 1 minute and 30 seconds. This difference is due to the time needed to carefully read the client's clinical information, fill the client's personal information when missing, conduct phone calls in case of incomplete information in the client profile update CUF Sintra Hospital's database and other bureaucratic tasks. As such, we clearly identified the lack of optimization in the organization and introduction of clinical data as one of the areas which should be improved upon to guarantee a more efficient notification process.

This project presents numerous benefits for the different participants, according to the role they played during the acute phase of the pandemic. For medical doctors, the possibility to work in collaboration with motivated and differentiated medical students in the case notification process, alleviated their administrative work. There was a notable gain in their availability to provide care for COVID-19 and non-COVID-19 clients.

From a public health perspective, the implementation of a faster and more effective case reporting system results in more realistically drawn pandemic curves and more reliable estimations of the community transmission chains. Thus, government decisions can be made more confidently with accurate data. 
Finally, an action plan for a second COVID-19 outbreak should be implemented as soon as possible given the current end of the state of emergency and gradual relaxation of the social distancing measures. A predefined approach strategy will allow for better management of our resources and a more successful response to a new COVID-19 outbreak.

\section{CONCLUSION}

Regarding the challenge imposed by the COVID-19 pandemic to the world, it is possible to infer that medical students contributed to the efficiency increase when notifying COVID-19 cases and that the main obstacle identified was the informatic software itself and its optimization.

The articulation amongst educational institutions and hospitals allow the integration of new skilled members to the working teams, diluting, therefore, the work volume that accumulates daily, under extraordinary circumstances, like a pandemic and the need to register each and every client tested.

We point out the need for tight cooperation between medical students and health institutions, not only to improve the resource and response management when facing COVID-19 in the near future, as well as for any other situation that poses a threat to the healthcare system in such a prejudicial way.

\section{ACKNOWLEDGEMENTS/ AGRADECIMENTOS}

The authors underline their profound appreciation to all professionals involved in this project for their indispensable contribution. To the José de Mello Saúde/ CUF Health Unit, a special gratitude for the opportunity and inherent growth, and to Patrícia Mora, MD for her permanent availability and interest in guiding the project. Finally, appreciations to all health professionals for their daily fight against the COVID-19 pandemic.

\section{ETHICAL DISCLOSURES}

CONFLICTS OF INTEREST: The authors have no conflicts of interest to declare.

FINANCIAL SUPPORT: This work has not received any contribution, grant or scholarship.

CONFIDENTIALITY OF DATA: The authors declare that they have followed the protocols of their work center on the publication of data from patients.
PROTECTION OF HUMAN AND ANIMAL SUBJECTS: The authors declare that the procedures followed were in accordance with the regulations of the relevant clinical research ethics committee and with those of the Code of Ethics of the World Medical Association (Declaration of Helsinki).

PROVENANCE AND PEER REVIEW: Not commissioned; externally peer reviewed.

\section{RESPONSABILIDADES ÉTICAS}

CONFLITOS DE INTERESSE: Os autores declaram a inexistência de conflitos de interesse na realização do presente trabalho.

FONTES DE FINANCIAMENTO: Não existiram fontes externas de financiamento para a realização deste artigo.

CONFIDENCIALIDADE DOS DADOS: Os autores declaram ter seguido os protocolos da sua instituição acerca da publicação dos dados de doentes.

PROTEÇÃO DE PESSOAS E ANIMAIS: Os autores declaram que os procedimentos seguidos estavam de acordo com os regulamentos estabelecidos pelos responsáveis da Comissão de Investigação Clínica e Ética e de acordo com a Declaração de Helsínquia da Associação Médica Mundial.

PROVENIÊNCIA E REVISÃO POR PARES: Não comissionado; revisão externa por pares.

\section{REFERENCES}

1. Lu R, Zhao X, Li J, Niu P, Yang B, Wu H, Wang W, Song H, Huang B, Zhu N, Bi Y. Genomic characterisation and epidemiology of 2019 novel coronavirus: implications for virus origins and receptor binding. Lancet. 2020;395:565-74. doi:10.1016/ S0140-6736(20)30251-8.

2. Huang C, Wang Y, Li X, Ren L, Zhao J, Hu Y, et al. Clinical features of patients infected with 2019 novel coronavirus in Wuhan, China. Lancet. 2020;395:497-506. doi:10.1016/ S0140-6736(20)30183-5.

3. World Health Organization. Coronavirus disease 2019 (COVID-19): Situation Report - 11. World Health Organization, 2020. [ accessed on 30-04-2020] Available from: https:// www.who.int/docs/default-source/coronaviruse/situation-reports/20200131-sitrep-11-ncov.pdf?sfvrsn=de7c0f7_4.

4. Direção-Geral da Saúde. Relatório de Situação nº 001 03/03/2020. Lisboa: DGS; 2020. [accessed 30-04-2020] Available from: https://covid19.min-saude.pt/wp-content/uploads/2020/03/Relato\%CC\%81rio-de-Situac\%CC\%A7a\%CC\%83o-1.pdf.

5. Direção-Geral da Saúde. Relatório de Situação no 059 | 30/04/2020. Lisboa: DGS; 2020. [accessed on 10-05-2020] Available from: https://covid19.min-saude.pt/wp-content/ uploads/2020/05/59_DGS_boletim_20200 -

6. Decreto do Presidente da República n. 14-A/2020. Diário da República n. 55/2020, $3^{\circ}$ Suplemento, Série I de 2020-03-18. [accessed on 10-05-2020] Available from: https://data.dre.pt/ eli/decpresrep/14-A/2020/03/18/p/dre. - 
7. Direção-Geral da Saúde. Sistema Nacional de Vigilância Epidemiológica (SINAVE). Orientação para Autoridades de Saúde e Unidades de Saúde Pública. Lisboa: DGS; 2015. [accessed on 10-05-2020] Available from: https://www.dgs.pt/servicos-on-line1/sinave-sistema-nacional-de-vigilancia-epidemiologica. aspx. 